$\begin{aligned} & \text { Idaho } \\ & \text { Pork-barrel politics } \\ & \text { actually works in } \\ & \text { funding US science } \\ & p 5\end{aligned}$
Why the public's
respect for experts
went up in flames
$p 6$

\title{
Europe lifts patent embargo on transgenic plants and animals...
}

\section{Munich}

The European Patent Office (EPO) has lifted a four-year moratorium on applications for patents on plants and animals, following a ruling by its top appeals board that such patents are not excluded by the wording of the European Patent Convention.

In 1995, a lower board of appeal overruled a patent issued to the Belgian company Plant Genetics Systems on a process for creating plants containing herbicide-resistance genes (see Nature 374, 8; 1995). The board's key reason was that the procedure could be used to create new 'varieties' of plants and that plant varieties were excluded from patentability by a clause in the convention.

A similar reason was used by the EPO which is not part of the European Union but is responsible for implementing the patent convention - to reject an application by the Swiss company Novartis to patent a process for creating transgenic plants containing pathogen-resistance genes, an application which included the plants produced by this process. The EPO president eventually referred Novartis's appeal to the organization's highest legal authority, the 'enlarged board of appeal', and asked for its interpretation of the crucial clause 53(b).

In a ruling made public on 20 December, the enlarged board overturned the earlier judgement. It ruled that the exclusion of plant varieties should be interpreted in a narrow sense, not used to deny patents on all plants produced by novel - and hence patentable - biotechnological processes.

Although this ruling brings the implementation of the patent convention in line with recent modifications to the European Union directive on patenting biotechnological processes (see Nature 388, $314 \& \mathbf{3 9 3}, 200$; 1998), the enlarged board made little reference to the directive. It argued from first principles that the exclusion of plant varieties from patent protection had a specific function: to let breeders continue applying their own procedures for plant variety protection, as defined by the International Union for the Protection of New Varieties of Plants.

The board considered that the wording of the patent convention, approved in the early NATURE |VOL 403 | 6 JANUARY 2000 | www.nature.com

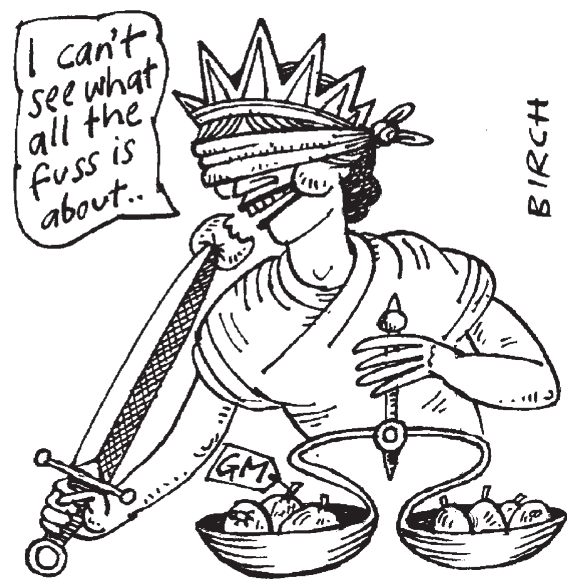

1970s, had been drawn up deliberately to ensure that plants could be protected either through patents or through traditional plant breeders' rights. It therefore concluded that there had been no intention to exclude plants (or animals) from patent protection as such.

The EPO has already started to process some 1,200 applications for patents on genetically altered animals and plants that have been on hold since 1995.

"This is a landmark decision for the whole seeds industry," says Walter Smolders, head of the patenting department of Novartis Seeds. He says that the "end to uncertainty about intellectual property" will promote development of useful crops and vegetables.

But the decision has been criticized by the environmental group Greenpeace, which campaigns against the patenting of life forms as "presumptuous and reprehensible".

Stefan Flothmann, head of the genetic engineering department at Greenpeace Germany, warns that the decision could lead to monopolies in the seeds market, and thus to higher costs and lower quality.

"If the production of seeds and food gets under control by few companies, the agricultural diversity will be reduced to a few patented varieties," says Flothmann. "In the long term, this is a threat to the world's food supplies." Quirin Schiermeier and David Dickson

\section{... as US tightens up on 'speculative' claims}

\section{Washington}

The US Patent and Trademark Office has released revised guidelines for patent inspectors that require applicants to "explicitly identify a specific and substantial utility" for genes and gene products - in other words, to specify an immediate and identifiable benefit to the public.

The guidelines were revised because of concerns that "people would claim utilities for which they had no substantial showing", says Todd Dickinson, the office's commissioner on patents and trademarks. Past applicants sometimes sought claims on 'naked' expressed sequence tags, he says, for which no known function was attributed. Those claims were rejected as too speculative, says Dickinson.

Some claimed 'throw-away' utility, saying that a protein could potentially be used as a food supplement or a shampoo additive. Applications quoting an unproven utility will now be rejected.

"We're trying to strike the right balance between the protection of innovation that these inventions represent and the access that the world - and in particular the research community — needs," says Dickinson.

Patent examiners are applying the new guidelines to applications already in the pipeline, including some that were filed provisionally.

Celera Genomics of Rockville, Maryland, announced last October that it had filed 6,500 provisional applications on genes it discovered while sequencing its first billion base pairs of human DNA. The subset it sends for examination will be subject to the more stringent rules. Paul Gilman Celera's director of policy and planning, says they "both expect and welcome" the new scrutiny.

Harold Varmus, outgoing director of the US National Institutes of Health, applauds the change. "I've been very pleased with the way [the patent office has] come closer to our position about the need to define specific utility," he says. The guidelines, available at http://www.uspto.gov, are open for public comment until 22 March. Paul Smaglik 